\title{
Communication
}

[Comunicação]

\section{Cytological and histopathological aspects of lipomas in Bothrops moojeni}

[Aspectos citológicos e histopatológicos de lipomas em Bothrops moojeni]

\author{
G.D. Cassali $^{1}$, V.F. Amaral ${ }^{1}$, A.E. Silva ${ }^{1}$, I. Macri ${ }^{1}$, R. Maciel ${ }^{2}$ \\ ${ }^{1}$ Laboratório de Patologia Comparada \\ ${ }^{1}$ Departamento de Patologia Geral- ICB - UFMG \\ Caixa Postal 486 \\ 31270-901 - Belo Horizonte, MG \\ ${ }^{2}$ Fundação Ezequiel Dias - Belo Horizonte
}

The neoplasms are among the most important causes of illness and mortality in the domestic animals (Moulton, 1990). However, tumors in reptiles are rare and there are few reports of neoplasms in ophidians (Ramsay et al., 1996; Marcello Jr. et al., 2002). The tumors in snakes have similar structures as those found in birds and mammals tumors. The difficulty in surviving with the presence of the tumor probably contributes to the apparent rarity of the observed neoplasms in these animals (Wadsworth, 1960).

There is a controversy in the observed reports in the literature in respect to the most frequent origin of the neoplasms in ophidian, which are malignant in the majority of the situations (Hubbard et al., 1983; Ramsay et al., 1996; Catão-Dias and Nichols, 1999). Some authors report mesenchymal neoplasms as the most frequent found (Catão-Dias and Nichols, 1999), while others indicate those of epithelial origin, but the most chosen site is the digestive system (Ramsay et al., 1996). However, all of the cases of ophidians neoplasm reported in San Antonio Zoo, during a period of 10 years, were malignant neoplasms derived from the mesenchymal tissue (Hubbard et al., 1983).
Lipoma is the most frequent benign neoplasm of mesenchymal origin observed in humans and in dogs while in other species it is relatively rare (Pulley and Stannard, 1990).

Depending on its anatomical and histological presentation, lipomas can still be classified as angiolipoma, pleomorfic lipoma, benign lipoblastoma, angiomiolipoma and spindle-cell lipoma (Weiss and Gols Bluem, 2001) each one less frequent than the considered lipoma.

The purpose of the following study is to describe the cytological and histopathological findings of six lipomas in Bothrops moojeni.

At Ezequiel Dias Foundation's serpentarium in Belo Horizonte-MG, the presence of subcutaneous nodules was observed in five ophidian females of Bothrops moojeni specie. These nodules are located from the proximal third to the medium portion of the body of the snakes. The animals were 7 to 14 years old and had an average length of 1.45 meters (Tab. 1).

Table 1. Tumors characteristics of the lipomas in Bothrops moojeni

\begin{tabular}{lcccccc}
\hline \multirow{2}{*}{ Tumor characteristic } & \multicolumn{5}{c}{ Ophidian } \\
\cline { 2 - 6 } & Case 1 & Case 2a & Case 2b & Case 3 & Case 4 & Case 5 \\
\hline Weight $(\mathrm{g})$ & 32.52 & 13.16 & 4.30 & 8.48 & 13.75 & 13.45 \\
Length $(\mathrm{cm})$ & 6.00 & 4.50 & 3.10 & 4.00 & 4.80 & 4.10 \\
Width $(\mathrm{cm})$ & 5.50 & 3.20 & 2.60 & 2.50 & 3.40 & 3.50 \\
Thickness $(\mathrm{cm})$ & 2.50 & 1.50 & 1.00 & 1.80 & 2.00 & 1.50 \\
\hline
\end{tabular}

Recebido para publicação em 28 de maio de 2003

Recebido para publicação, após modificações, em 21 de novembro de 2003

E-mail: cassalig@mono.icb.ufmg.br 
The tumors presented, macroscopically, a nodular aspect (Fig. 1A), soft consistency and white strawyellow coloration. Upon incision, masses with fatty aspects were evidenced, delimitated by the presence of an individual capsule. Fine needle aspirated punctures were performed, using a disposable syringe of $10 \mathrm{ml}$ and needle of $25 \times 6 \mathrm{~mm}$. Smears of the aspirated material were done, air dried and subsequently stained with May-Grünwald Giemsa or immediately fastened in alcohol 96 for Papanicolau stain. The fragments were processed by paraffin inclusion techniques and stained with hematoxilin-eosin for histological evaluation.

The cytological exams stained with Giemsa and Papanicolau showed bunches of fusiform cells mixed with cells of cytoplasm filled with a large and single vacuole in negative image compressing the nucleus to the periphery (Fig. 1B-C).
Centralized nucleus and cytoplasm with multiple vacuoles in negative image were observed in other cells. These nuclei were fusiform, small, with homogeneous chromatin and without mitotic figures.

At the histopathological exam nodules constituted by round cells, with outlying nucleus and cytoplasm filled with a large and single vacuole in negative image, were observed. These nodules were similar to mature adipocytes, mixed with fusiform cells and multivacuolated cells, showing little celular pleomorphism, central nuclei and, at times, proeminent nucleoli mitotic figures were not observed (Fig. 1D). Some foci of mononuclear inflammatory infiltrate and eosinophils were also present. Staining with Sudan III showed presence of lipid droplets in the cytoplasm of the tumor cells.
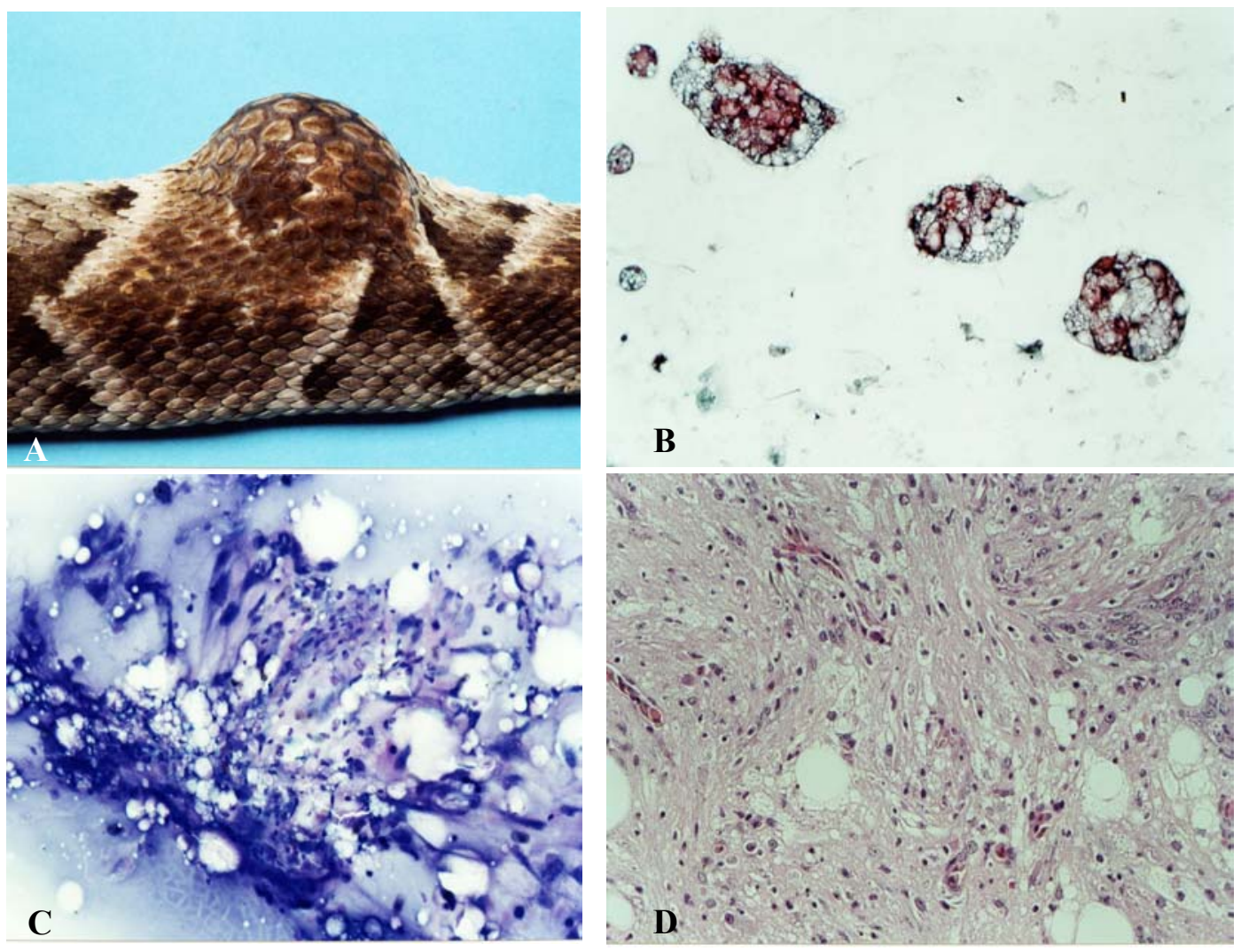

Figure 1. Botrophs moojeni. Lipoma. (A) Macroscopy. Nodular aspect. (B) Cythological aspects. Bunches of fusiform cells mixed with cells of cytoplasm filled with a large and single vacuole in negative image. Papanicolaou. 10× (C) Cytological aspects. Giemsa. 10× (D) Histopathogical. Round cells, with outlying nucleus and cytoplasm filled with a large and single vacuole in negative image, similar to mature adipocytes, mixed with fusiform cells and multivacuolated cells. HE. 10×. 


\section{Cytological and histopathological aspects of lipomas in Bothrops moojeni}

Based on the cytological and histological findings, the results showed evidences of benign lipomatous tumors which are compatible with the subtype spindle-cell lipoma. The spindle-cell lipomas are characterized by the association of mature adipocytes, fusiform cells, collagen fiber fragments and mixomatous matrix (Agoff et al., 2001). These neoplasms represent approximate $1 y 1.5 \%$ of the observed lipomas in the human species and are considered rare
(Fletcher and Martin-Bates, 1987; Guo et al., 2000; Agoff et al., 2001). Although these tumors allow the biopsy by aspirated puncture, as a result of the superficial nature of their lesions, there are few cytological descriptions of spindlecell lipoma in the literature.

Keywords: Bothrops moojeni, lifoma, tumor, neoplasm

\section{RESUMO}

O presente relato descreve os achados citológicos e histológicos de seis neoplasias benignas em cinco ofidios da espécie Bothrops moojeni mantidas em cativeiro por um período médio de 11,4 anos. Os animais apresentavam nódulos subcutâneos com localização variada desde o terço anterior até a porção mediana. Os exames citológico e histopatológico revelaram tratar-se de tumores lipomatosos benignos compativeis com o subtipo lipoma fusocelular.

Palavras-chave: Bothrops moojeni, lipoma, tumor, neoplasia

\section{REFERENCES}

AGOFF, S.N.; FOLPE, A.; GRIECO, V.S. et al. Spindle cell lipoma of the oral cavity. Acta Cytol., v.45, p.93-98, 2001.

CATÃO-DIAS, J.L.; NICHOLS, D.K. Neoplasia in snakes at the National Zoological Park, Washington, DC (1978-1997). J. Comp. Pathol., v.120, p.89-95, 1999.

FLETCHER, C.; MARTIN-BATES, E. Spindle cell lipoma: a clinicopathologic study with some original observations. Histopathology., v.11, p.803-817, 1987.

GUO, Z.; VOYTOVICH, M.; KURTYCZ, D. Fine-needle aspiration diagnosis of spindle-cell lipoma: a case report and review of the literature. Diagn. Citopathol., v.23, p.362-356, 2000.

HUBBARD, G.B.; SCMIDT, R.E.; FLETCHER, K.C. Neoplasia in zoo animals. J. Zoo Wildl. Med., v.14, p.33-40, 1983.

MARCELLO Jr., H.B.; MACIEL, R.; RIBEIRO, C.A. et al. Spindle cell sarcoma in Bothrops leucurus. Arq. Bras. Med. Vet. Zootec., v.54, p.325-327, 2002.

MOULTON, J.E. Tumors in domestic animals. 3.ed. Berkeley: University of California, 1990. $672 \mathrm{p}$.

PULLEY, L.T.; STANNARD, A.A. Tumors of the skin and soft tissues. In: MOULTON, J. E. (Ed.). Tumors in domestic animals. 3.ed. Berkeley: University of California, 1990. P.2387.

RAMSAY, E.C.; MUNSON, L.; LOWENSTINE, L. et al. A restrospective study of neoplasia in collection of snakes. J. Zoo. Wildl. Med., v. 27, p. 28-34, 1996.

WADSWORTH, J.R. Tumors and tumor-like lesion of snakes. J. Am. Vet. Med. Assoc., v.137, p.419-420, 1960.

WEISS, S.W.; GOLS BLUEM, J.R. Benign lipomatous tumors. In: Enzinger and Weiss's soft tissues tumors. 4.ed. St Louis: Mosby, 2001. P.571-639. 